\title{
Detection of Coconut cadang-cadang viroid (CCCVd) in oil palm by reverse transcription loop-mediated isothermal amplification (RT-LAMP)
}

\begin{abstract}
A reverse transcription loop-mediated isothermal amplification (RT-LAMP) detected Coconut cadang-cadang viroid $(\mathrm{CCCVd})$ within $60 . \mathrm{min}$ at $60 .{ }^{\circ} \mathrm{C}$ in total nucleic acid extracted from oil palm leaves infected with CCCVd. Positive reactions showed colour change from orange to green in the reaction mix after the addition of fluorescent reagent, and a laddering pattern band on $2 \%$ agarose gel electrophoresis. Conventional RT-PCR with LAMP primers produced amplicons with a sequence identical to the 297-nt CCCVd oil palm variant with the primers being specific for CCCVd and not for other viroids such as PSTVd and CEVd. RT-LAMP was found to be rapid and specific for detecting oil palm CCCVd.
\end{abstract}

Keyword: Coconut cadang-cadang viroid; Oil palm; RT-LAMP 